\title{
Celastrol ameliorates cytokine toxicity and pro-inflammatory immune responses by suppressing NF- $\kappa B$ activation in RINm5F beta cells
}

\author{
Sung Mi Ju, Gi Soo Youn, Yoon Shin Cho, Soo Young Choi \& Jinseu Park \\ Department of Biomedical Science and Research Institute for Bioscience \& Biotechnology, Hallym University, Chunchon 200-702, Korea
}

\begin{abstract}
Upregulation of pro-inflammatory mediators contributes to $\beta$-cell destruction and enhanced infiltration of immune cells into pancreatic islets during development of type 1 diabetes mellitus. In this study, we examined the regulatory effects and the mechanisms of action of celastrol against cytotoxicity and pro-inflammatory immune responses in the RINm5F rat pancreatic $\beta$-cell line stimulated with a combination of interleukin-1 beta, tumor necrosis factor-alpha, and interferon- $\gamma$. Celastrol significantly restored cytokine-induced cell death and significantly inhibited cytokine-induced nitric oxide production. In addition, the protective effect of celastrol was correlated with a reduction in pro-inflammatory mediators, such as inducible nitric oxide synthase, cyclooxygenase-2, and CC chemokine ligand 2. Furthermore, celastrol significantly suppressed cytokine-induced signaling cascades leading to nuclear factor kappa B (NF-KB) activation, including IKB-kinase (IKK) activation, IKB degradation, p65 phosphorylation, and p65 DNA binding activity. These results suggest that celastrol may exert its cytoprotective activity by suppressing cytokine-induced expression of pro-inflammatory mediators by inhibiting activation of NF-KB in RINm5F cells. [BMB Reports 2015; 48(3): 172-177]
\end{abstract}

\section{INTRODUCTION}

The hallmark of type 1 diabetes mellitus (T1DM) is selective destruction of the insulin-producing pancreatic $\beta$-cells via the inflammatory response (reviewed in [1]). Various cytokines, such as interleukin-1beta (IL-1 $\beta$ ), interferon gamma (IFN- $\gamma$ ), and tumor necrosis factor alpha (TNF- $\alpha$ ), are produced from activated immune cells that infiltrate the islets during development of T1DM. These pro-inflammatory cytokines are important mediators that induce loss of pancreatic $\beta$-cells $(2,3)$.

${ }^{*}$ Corresponding author. Tel: +82-33-248-2116; Fax: +82-33-2563420; E-mail: jinpark@hallym.ac.kr

http://dx.doi.org/10.5483/BMBRep.2015.48.3.147

Received 15 July 2014, Revised 23 July 2014, Accepted 23 July 2014

Keywords: $\beta$-cell, Celastrol, Cytokine, Inflammation, NF-кB
The molecular mechanisms underlying $\beta$-cell destruction include upregulation of inducible nitric oxide synthase (iNOS) and cyclooxygenase-2 (COX-2), leading to enhanced production of nitric oxide $(\mathrm{NO})$ and prostaglandin $\mathrm{E}_{2}$, respectively $(2,4)$. In addition, various chemokines including CC chemokine ligand 2 (CCL2; monocyte chemoattractant protein-1), CXC chemokine ligand 8 (CXCL8; IL-8), and CXCL10 (IFN- $\gamma$-induced protein-10) may contribute to $\beta$-cell destruction by recruiting various immune cells into the pancreatic islets $(5,6)$.

Nuclear factor kappa B (NF-kB) signaling pathways predominantly regulate cell death and expression of various inflammatory mediators, such as iNOS, COX-2, and CCL2 in pancreatic $\beta$-cells (7). Cytokine stimulation initially activates the $I \kappa B-$ kinase (IKK) complex, which consists of two kinase subunits (IKK $\alpha$ and IKK $\beta$ ) and the IKK $\gamma / \mathrm{NEMO}$ regulatory subunit. In turn, IKK rapidly phosphorylates $I \kappa B \alpha$ on Ser32 and Ser36, resulting in its ubiquitination and subsequent proteasomal degradation (8). NF- $\kappa B$ dissociates from $I \kappa B \alpha$ and translocates to the nucleus, where it activates gene transcription of inflammatory mediators.

Celastrol, a quinone methide triterpenoid, is a major constituent from Tripterygium wilfordii Hook with biological activities and has been used widely as a traditional medicine to control various inflammatory diseases (9). Celastrol has anti-inflammatory activities in various inflammatory disease models (reviewed in [10]). Although celastrol does not prevent diabetes in NOD mice, it transiently lowers blood glucose (11). In addition, celastrol inhibits insulin resistance and diabetic nephropathy, possibly by inhibiting NF-אB activity in a type 2 diabetic animal model (12). Despite its beneficial effects on several diabetic conditions, the protective effect of celastrol on pancreatic $\beta$-cells has not been determined. In this study, we investigated the regulatory effect of celastrol on cytokine-induced cell death, expression of pro-inflammatory mediators, and NF- $\mathrm{KB}$ signaling cascades in RINm5F rat pancreatic $\beta$-cells.

\section{RESULTS}

Celastrol reverses the cytotoxic effect of cytokines in RINm5F cells

We used the RINm5F rat pancreatic $\beta$-cell line, which is a

ISSN: 1976-670X (electronic edition)

Copyright (c) 2015 by the The Korean Society for Biochemistry and Molecular Biology

(c) This is an open-access article distributed under the terms of the Creative Commons Attribution Non-Commercial License (http://creativecommons.org/licenses/by-nc/3.0) which permits unrestricted non-commercial use, distribution, and reproduction in any medium, provided the original work is properly cited. 
A

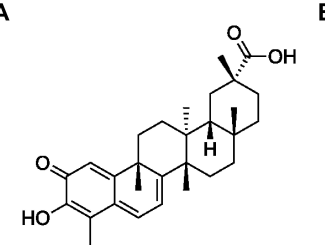

B $\quad{ }^{120}$
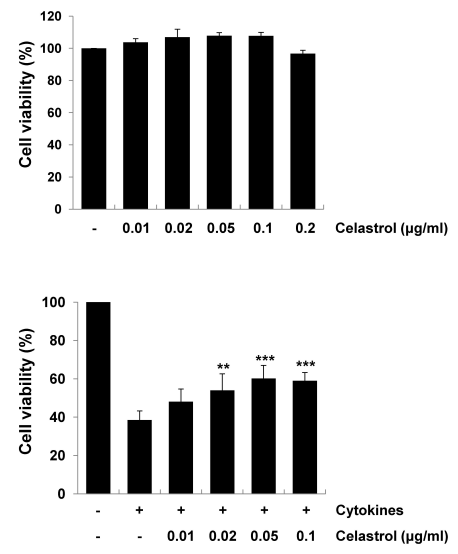

Fig. 1. Protective effect of celastrol on cytokine-induced cytotoxicity in RINm5F cells. (A) Chemical structure of celastrol. (B) RINm5F cells were incubated with various concentrations of celastrol for $24 \mathrm{~h}$, and then celastrol cytotoxicity was determined by the MTT assay. (C) Cells were pretreated with celastrol at varying doses for $1 \mathrm{~h}$ and then stimulated with cytokines $(5 \mathrm{ng} / \mathrm{ml}$ interleukin [IL]-1 $\beta$, $10 \mathrm{ng} / \mathrm{ml}$ tumor necrosis factor [TNF]- $\alpha$, and $10 \mathrm{ng} / \mathrm{ml}$ interferon [IFN]- $\gamma$ ). At $24 \mathrm{~h}$ after stimulation, cell viability was determined by the MTT assay. Results are expressed as mean \pm standard deviation of three independent experiments. $* * P<0.01, * * * P<0.001$ compared to the cytokine-treated group.

widely used model to study $\beta$-cell death and inflammation. We first performed the MTT assay to evaluate the toxic effect of celastrol (Fig. 1A) on RINm5F cells. As shown in Fig. 1B, celastrol did not significantly affect cell viability at the concentrations tested. We next examined the protective effect of celastrol on cytokine-induced cell death. RINm5F cells were exposed to various concentrations of celastrol in the presence of a combination of cytokines $(5 \mathrm{ng} / \mathrm{ml} \mathrm{IL-1 \beta ,10} \mathrm{ng/ml} \mathrm{TNF-} \alpha$, and $10 \mathrm{ng} / \mathrm{ml} \mathrm{IFN}-\gamma$ ) for $24 \mathrm{~h}$, and cell viability was determined by the MTT assay. Treatment of RINm5F cells with cytokines alone resulted in about $62 \%$ cell death, compared to that in control cells. However, celastrol significantly increased cell viability in a dose-dependent manner $(\sim 56 \%$ at $0.05 \mu \mathrm{g} / \mathrm{ml})$, suggesting a protective effect of celastrol in cytokine-stimulated RINm5F cells (Fig. 1C).

\section{Celastrol inhibits iNOS and subsequent production of NO in} cytokine-stimulated RINm5F cells

Inflammatory cytokines, such as IL- $1 \beta, \mathrm{TNF}-\alpha$, and IFN- $\gamma$, exert toxic effects on pancreatic $\beta$-cells by inducing iNOS expression and subsequent $\mathrm{NO}$ production (reviewed in [7]). NO is a major mediator inducing cell death by altering mitochondrial metabolism and modifying proteins in pancreatic $\beta$-cells (13). To examine the regulatory effect of celastrol on cytokine-induced NO production, RINm5F cells were pretreated with various concentrations of celastrol for $1 \mathrm{~h}$, stimulated with cytokines for $24 \mathrm{~h}$, and then nitrite levels in the medium were evaluated using the Griess reaction. Stimulating RINm5F

A

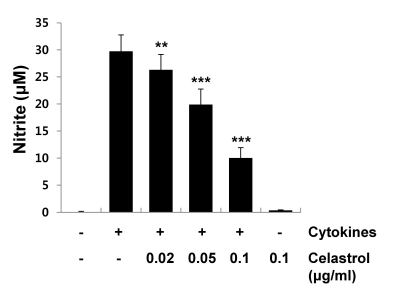

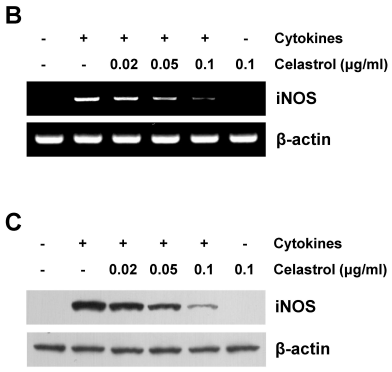

B
Fig. 2. Inhibitory effect of celastrol on cytokine-induced inducible nitric oxide synthase (iNOS) expression and nitric oxide (NO) production in RINm5F cells. (A) RINm5F cells were pretreated with varying doses of celastrol for $1 \mathrm{~h}$, and then stimulated with cytokines $(5 \mathrm{ng} / \mathrm{ml}$ interleukin [IL]-1 $\beta, 10 \mathrm{ng} / \mathrm{ml}$ tumor necrosis factor $[\mathrm{TNF}]-\alpha$, and $10 \mathrm{ng} / \mathrm{ml}$ interferon [IFN]- $\gamma$ ) for $12 \mathrm{~h}$. Total RNA was harvested and analyzed by reverse transcription-polymerase chain reaction using iNOS-specific primers. (B) Cells were pretreated with celastrol for $1 \mathrm{~h}$, followed by stimulation with cytokines for $24 \mathrm{~h}$. Whole cell lysates were analyzed by Western blotting using an antibody against iNOS and $\beta$-actin. (C) NO concentrations in culture medium were determined by the Griess reaction. ${ }^{*} * \mathrm{P}<0.01$, $* * * \mathrm{P}<0.001$ compared to the cytokine-treated group.

cells with cytokines markedly increased NO production, whereas a $1 \mathrm{~h}$ pretreatment with celastrol resulted in a significant reduction in $\mathrm{NO}$ levels in a dose-dependent manner in cytokine-stimulated RINSm5F cells (Fig. 2A). NO production in cytokine-stimulated RINm5F cells was attributed to upregulation of iNOS expression. Therefore, we investigated the inhibitory effects of celastrol on cytokine-induced iNOS expression. Cells pretreated with celastrol for $1 \mathrm{~h}$ were stimulated with cytokines, and iNOS mRNA and protein expression levels were measured by reverse transcription-polymerase chain reaction (RT-PCR) and Western blot analyses, respectively. As shown in Fig. 2B and 2C, celastrol significantly inhibited iNOS mRNA and protein expression in a dose-dependent manner in cytokine-stimulated RINm5F cells. These results support that inhibiting NO production with celastrol is correlated with inhibited iNOS expression in cytokine-stimulated RINm5F cells. These results contribute to the protective effect of celastrol against cytokine-induced cell death.

\section{Celastrol inhibits cytokine-induced expression of COX-2 and CCL2 in RINm5F cells}

Stimulating pancreatic $\beta$-cells with cytokines, such as IL-1 $\beta$, $\mathrm{TNF}-\alpha$, and IFN- $\gamma$, induces the expression of pro-inflammatory mediators, such as COX-2 and chemokines including CCL2, CXCL8, and CXCL10 (5, 6, 14). These chemokines are implicated in the recruitment and activation of immune cells, such as monocytes and T cells, into pancreatic islets during development of $\operatorname{T1DM}(6,14)$. We further examined the effect of celastrol on the expression of pro-inflammatory mediators, such as COX-2, CCL2, CXCL8 and CXCL10, in cytokine-stimulated RINm5F cells. The cells were pretreated with celastrol for 

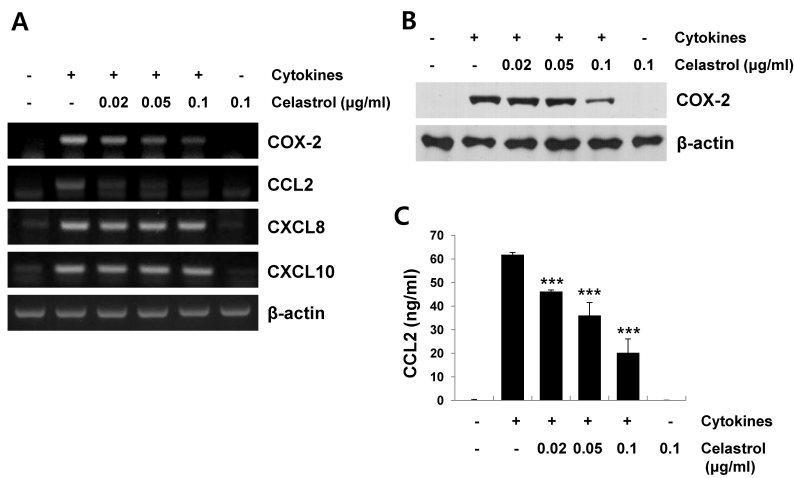

Fig. 3. Inhibitory effect of celastrol on cytokine-induced pro-inflammatory mediators in RINm5F cells. Cells were incubated with celastrol for $1 \mathrm{~h}$, and then exposed to cytokines $(5 \mathrm{ng} / \mathrm{ml}$ interleukin [IL]-1 $\beta, 10 \mathrm{ng} / \mathrm{ml}$ tumor necrosis factor [TNF]- $\alpha$, and $10 \mathrm{ng} / \mathrm{ml}$ interferon [IFN]- $\gamma$ ) for $12 \mathrm{~h}$ (for mRNA) or $24 \mathrm{~h}$ (for protein). (A) Cyclooxygenase (COX)-2, CC chemokine ligand (CCL)2, CXCL8, CXCL10, and $\beta$-actin mRNA levels were determined by reverse transcription-polymerase chain reaction using specific primers. (B) COX-2 protein expression in cytokine-stimulated cells was measured by Western blot analysis using antibodies against COX-2 and $\beta$-actin. (C) CCL2 production in the culture medium was determined using an enzyme-linked immunosorbent assay kit. Data are mean \pm standard deviation of three experiments. ${ }^{* * * P}<0.001$ compared to the cytokine-treated group.

$1 \mathrm{~h}$, and stimulated with cytokines for $12 \mathrm{~h}$ to analyze mRNA expression or for $24 \mathrm{~h}$ to analyze protein expression. As shown in Fig. 3A, celastrol significantly decreased cytokine-induced COX-2 and CCL2 mRNA expression in a dose-dependent manner. However, no significant reduction in cytokine-induced CXCL8 and CXCL10 mRNA levels was observed when the cells were pretreated with celastrol. Celastrol inhibited cytokine-induced COX-2 protein expression, as determined by Western blot analysis (Fig. 3B). We also analyzed the culture supernatants for levels of the CCL2 protein by enzyme-linked immunosorbent assay (ELISA). Similar to the CCL2 mRNA level, celastrol significantly inhibited cytokine-induced production of CCL2 in a dose-dependent manner (Fig. 3C).

\section{Celastrol inhibits cytokine-induced signaling cascades leading to NF- $\kappa \mathrm{B}$ activation in RINm5F cells}

$\mathrm{NF}-\mathrm{\kappa B}$ is a principal transcription factor for the expression of various proinflammatory mediators, such as iNOS, COX-2, and cytokines/chemokines $(7,15)$. Signaling cascades leading to NF- $\kappa B$ activation include IKK activation, I $\mathrm{K} B \alpha$ degradation, and p65 phosphorylation (8). We first investigated the effect of celastrol on cytokine-induced IKK $\alpha / \beta$ activation. Total and phosphorylated forms of IKK in cell lysates were determined to evaluate the degree of IKK $\alpha / \beta$ activation. As shown in Fig. $4 \mathrm{~A}$, celastrol significantly inhibited cytokine-induced IKK $\alpha / \beta$ phosphorylation. Next, we evaluated the suppressive effect of celastrol on cytokine-induced downstream signaling cascades leading to NF-KB activation after IKK activation. As shown in Fig.
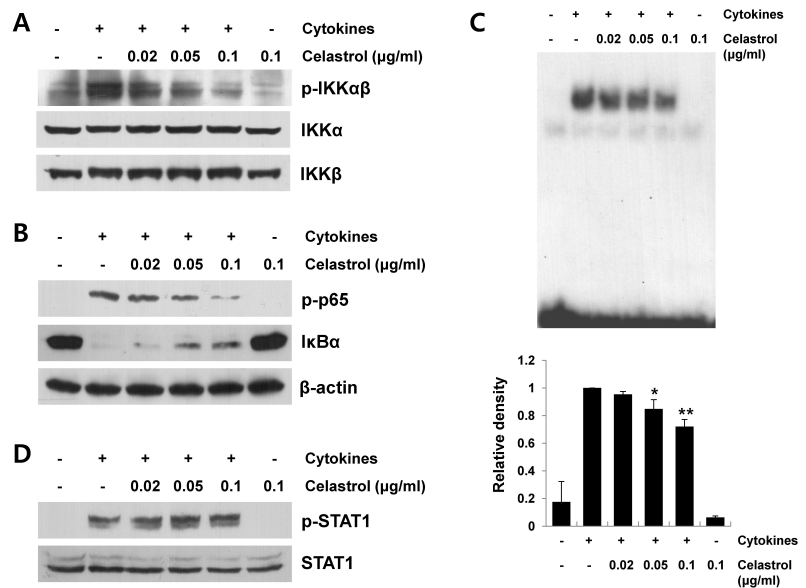

Fig. 4. Effect of celastrol on the signaling cascades leading to nuclear factor kappa B (NF-kB) activation in cytokine-stimulated RINm5F cells. Cells were pretreated with celastrol at the indicated concentrations for $1 \mathrm{~h}$ and then stimulated with cytokines $(5 \mathrm{ng} / \mathrm{ml}$ interleukin [IL]-1 $\beta, 10 \mathrm{ng} / \mathrm{ml}$ tumor necrosis factor [TNF]- $\alpha$, and $10 \mathrm{ng} / \mathrm{ml}$

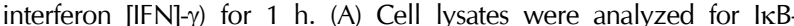
kinase (IKK) $\alpha / \beta$ activation by Western blot analysis using phospho-specific antibodies. (B) p65 and $1 \kappa B \alpha$ levels in cell lysates were determined by Western blot analysis. (C) DNA-binding activity of NF- $\kappa B$ in the cell nuclear extracts was measured by electrophoretic mobility shift assay using a NF- $\mathrm{B}$ p 65 specific oligonucleotide probe. Band intensity was quantified by scanning densitometry and presented as bar graphs (mean \pm standard deviation, $\mathrm{n}=3$ ) in the bottom panel. ${ }^{*} \mathrm{P}<0.05, * * \mathrm{P}<0.01$ compared to the cytokine-treated group. (D) Cell lysates were prepared from RINm5F cells stimulated with cytokines for $1 \mathrm{~h}$ and the levels of phosphorylated signal transducer and activator of transcription 1 (STAT1) were measured by Western blot analysis using a phospho-specific antibody.

$4 \mathrm{~B}$, celastrol significantly suppressed $\mathrm{I} \kappa \mathrm{B} \alpha$ degradation and p65 phosphorylation in cytokine-stimulated RINm5F cells. In addition, celastrol inhibited cytokine-induced p65 DNA-binding activity, as measured by electrophoretic mobility shift assay (EMSA) (Fig. 4C). However, celastrol did not affect cytokine-induced signal transducer and activator of transcription 1 (STAT1) activation (Fig. 4D). These findings suggest that suppressing signaling cascades leading to NF-kB activation is a mechanism by which celastrol inhibits expression of proinflammatory mediators, such as iNOS, COX-2 and CCL2, in cytokine-stimulated RINm5F cells.

\section{DISCUSSION}

The most common feature of T1DM is loss of pancreatic $\beta$-cells via autoimmune responses (1). When stimulated by inflammatory cytokines (e.g., IL-1 $\beta$, TNF- $\alpha$, and IFN- $\gamma$ ), insulinproducing pancreatic $\beta$-cells express increased levels of iNOS and COX-2, as well as chemokines such as CCL2, which mediate destructive events in the pancreatic islets $(3,6)$. Therefore, any interventions in the steps involved in cell death and 
pro-inflammatory responses may provide a rationale for the development of therapeutic agents against T1DM.

During pathogenic processes of inflammatory diseases including type 1 diabetes, macrophages and T cells infiltrate the pancreas, and produce various cytokines, such as IL-1 $\beta$, TNF- $\alpha$, and IFN- $\gamma$, which mediate selective $\beta$-cell dysfunction and death (reviewed in [7]). Previous reports have suggested that these cytokines induce cell death in synergistic fashion (reviewed in [16]). The combination of IL-1 $\beta$, TNF- $\alpha$, and IFN- $\gamma$ under our experimental conditions induced cell death in about $60 \%$ of RINm5F cells. However, cytokine-induced cell death was significantly inhibited by pretreatment with celastrol (Fig. 1C), indicating its protective effect in cytokine-stimulated RINm5F cells. It has been suggested that cytokine-induced iNOS expression and subsequent NO production have functional correlations with the dysfunction and destruction of $\beta$ cells (4). We observed that celastrol suppressed iNOS expression and subsequent $\mathrm{NO}$ production in cytokine-stimulated RINm5F cells (Fig. 2). In addition, celastrol significantly inhibited cytokine-induced COX-2 expression (Fig. 3A and B). The inhibited iNOS and COX-2 expression may have contributed to the protective effect of celastrol against cytokine-induced cell death.

Chemokines, such as CCL2, CXCL8, CXCL10, are also mediators of $\beta$-cell death by recruiting various immune cells into the pancreatic islets $(5,6)$. Previous studies have demonstrated that increased CCL2, CXCL8, and CXCL10 expression levels are associated with disease progression in T1DM models $(5,6$, 17). Although resident macrophages and endothelial cells primarily secrete these chemokines, $\beta$ cells release various chemokines including CCL2 upon stimulation by cytokines (reviewed in [16]). We found that celastrol significantly decreased CCL2 production in cytokine-stimulated cells, whereas CXCL8 and CXCL10 levels were not lowered (Fig. 3). The differential effect of celastrol on chemokine expression may be due to the distinct pathways leading to chemokine expression.

$\mathrm{NF}-\mathrm{KB}$ activation is involved in pro-apoptotic and inflammatory responses. Therefore, modulating NF- $\mathrm{kB}$ activation is a promising strategy to develop therapeutic targets against T1DM (18). Various stimuli including cytokines activate the IKK complex, consisting of IKK $\alpha, I K K \beta$, and IKK $\gamma / \mathrm{NEMO}$, which in turn activates downstream signaling cascades leading to NF- $\mathrm{KB}$ activation (19). As shown in Fig. 4A, celastrol significantly inhibited cytokine-induced IKK phosphorylation. A previous study revealed that celastrol suppresses IKK activity, possibly by directly targeting cysteine 179 in IKK (20). Celastrol also suppressed cytokine-induced I $\mathrm{K} \mathrm{B} \alpha$ degradation, p65 phosphorylation, and DNA-binding activity of p65 NF-kB (Fig. 4B and C). Cytokines utilize diverse transcriptional factors other then NF- $\kappa B$, such as STAT1 and activator protein 1, leading to up-regulation of gene transcription related to $\beta$-cell death (reviewed in [7]). However, celastrol did not affect cytokine-induced STAT1 (Fig. 4D) or c-Jun activation (data not shown) under our experimental conditions. Taken together, these data suggest that celastrol exerts protective effects against cytokine-induced cell death and pro-inflammatory responses by suppressing NF- $\kappa B$ signaling pathways

In conclusion, we provide evidence that celastrol regulated cytokine-induced cell death and pro-inflammatory responses by downregulating iNOS and COX-2, as well as chemokines such as CCL2 in RINm5F cells. Celastrol exerted its protective effects against cytokine-stimulated RINm5F cells by intervening in NF- $\kappa B$ signaling pathways. Elucidating the mechanisms of action by which celastrol modulates dysfunction of pancreatic $\beta$-cells may provide the molecular basis for developing therapeutic agents against T1DM.

\section{MATERIALS AND METHODS}

\section{Cell culture and reagents}

The RINm5F rat pancreatic $\beta$-cell line was obtained from the American Type Culture Collection (Manassas, VA, USA) and maintained in RPMI 1640 medium supplemented with $10 \%$ fetal bovine serum, $2 \mathrm{mM}$ L-glutamine, and antibiotics (100 $\mathrm{U} / \mathrm{ml}$ penicillin $\mathrm{G}$ and $100 \mu \mathrm{g} / \mathrm{ml}$ streptomycin) at $37^{\circ} \mathrm{C}$ in a humidified incubator containing $5 \% \mathrm{CO}_{2}$ and $95 \%$ air. IL-1 $\beta$, TNF- $\alpha$, and IFN- $\gamma$ were obtained from R\&D Systems (Minneapolis, $M N$, USA). Primary antibodies against iNOS, COX-2, and $\beta$-actin were obtained from Santa Cruz Biotechnology (Santa Cruz, CA, USA). Celastrol, HRP-conjugated anti-rabbit or goat antibodies were supplied by Sigma (St. Louis, MO, USA). All other reagents were from Sigma-Aldrich.

\section{Cell viability assay}

Cell viability was monitored by the 3-[4,5-dimethylthiazol-2-yl]2,5-diphenyltetrazolium bromide (MTT) assay with a slight modification (21). Briefly, RINm5F cells were seeded at $1 \times$ $10^{5}$ cells/well in a 96-well plate. The cells were incubated with different concentrations of celastrol with or without a combination of cytokines $(5 \mathrm{ng} / \mathrm{ml} \mathrm{IL}-1 \beta, 10 \mathrm{ng} / \mathrm{ml} \mathrm{TNF-} \alpha$, and 10 $\mathrm{ng} / \mathrm{ml} \mathrm{IFN}-\gamma)$ for $24 \mathrm{~h}$ in serum-free media. MTT solution $(1$ $\mathrm{mg} / \mathrm{ml}$ ) was added to each well and incubated at $37^{\circ} \mathrm{C}$ for 30 $\mathrm{min}$. After the culture supernatants were removed, $0.5 \mathrm{~mL}$ isopropanol was added to dissolve the blue formazan crystals. Absorbance was measured at $570 \mathrm{~nm}$ with a microplate reader.

\section{Nitrite determination}

RINm5F cells seeded at $1 \times 10^{6}$ cells/well in a 6-well plate were cultured for $24 \mathrm{~h}$ in complete media. The cells were treated with celastrol for $1 \mathrm{~h}$ and then stimulated with cyto-

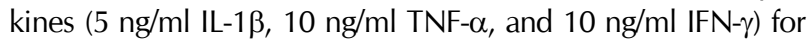
$24 \mathrm{~h}$ in serum-free media. The amount of nitrite in the culture medium was measured using the Griess reagent system (Promega, Madison, WI, USA) (21).

\section{Westem blot analysis}

Cellular or nuclear extracts were prepared in a lysis buffer (50 $\mathrm{mM}$ Tris- $\mathrm{HCl}, 150 \mathrm{ml} \mathrm{NaCl}, 1 \mathrm{mM}$ EDTA, 1 mM PMSF, 1 
$\mu \mathrm{g} / \mathrm{ml}$ leupeptin, $1 \mathrm{mM} \mathrm{Na} \mathrm{VO}_{4}, 1 \mathrm{mM} \mathrm{NaF}, 1 \% \mathrm{NP}-40$, and $0.25 \%$ sodium deoxycholate). The protein concentrations in the samples were measured using the Bradford protein assay (Bio-Rad, Hercules, CA, USA). Proteins in samples were separated on $10 \%$ SDS-polyacrylamide gels and transferred to nitrocellulose membranes. The membranes were blocked with $10 \%$ nonfat dry milk in TBST buffer $(137 \mathrm{mM} \mathrm{NaCl}, 20 \mathrm{mM}$ Tris- $\mathrm{HCl}, \mathrm{pH} 7.6$, and $0.1 \%$ Tween 20 ) for $1 \mathrm{~h}$, and incubated with primary antibodies at $4^{\circ} \mathrm{C}$ overnight. After washing with TBST three times, the membranes were incubated with HRPconjugated primary antibodies for $2 \mathrm{~h}$ at room temperature. Immunoreactive proteins were detected by a chemiluminescence system (Amersham Life Sciences, Parsippany, NJ, USA) (22)

\section{RT-PCR analysis}

Total cellular RNA was extracted from RINm5F cells using a Trizol reagent kit (Invitrogen, Gaithersburg, MD, USA), according to the manufacturer's instructions. CDNA was generated from total RNA $(2 \mu \mathrm{g})$ using $10,000 \mathrm{U}$ of reverse transcriptase and $0.5 \mu \mathrm{g} / \mu \mathrm{l}$ oligo-(dT) 15 primer (Promega, Madison, WI, USA) (23). PCR amplification of cDNA was performed using the following sense and antisense primers $\left(5^{\prime} \rightarrow 3^{\prime}\right)$ : iNOS sense, TTG GGT CTT GTT AGC CTA GTC; iNOS antisense, TGT GCA GTC CCA GTG AGG AAC; COX-2 sense, CTG TAT CCC GCC CTG CTG GT; COX-2 antisense, ACT TGC GYY GAT GGC TG ; CCL2 sense, GTT GTT CAC AGT TGC TGC CT; CCL2 antisense, CTC TGT CAT ACT GGT CAC TT; CXCL8 sense, GAA GAT AGA TTG CAC CGA TG; CXCL8 antisense, CAT AGC CTC TCA CAC ATT TC; CXCL10 sense, CCG CGC CTA TCG CCA ATG AGC TGC GC; CXCL10 antisense, CTT GGG GAC ACC TTT TAG CAT CTT TTG G; beta-actin sense, GAC CGA GCG TGG CTA CAG C; beta-actin antisense, TGT CAG CGA TGC CTG GGT AC. PCR products were resolved on a $1 \%$ agarose gel and visualized with UV light after staining with ethidium bromide.

\section{ELISA}

RINm5F cells were pretreated with celastrol for $1 \mathrm{~h}$ and then stimulated with cytokines $(5 \mathrm{ng} / \mathrm{ml} \mathrm{IL}-1 \beta, 10 \mathrm{ng} / \mathrm{ml} \mathrm{TNF}-\alpha$, and $10 \mathrm{ng} / \mathrm{ml} \mathrm{IFN}-\gamma$ ) for $24 \mathrm{~h}$. Culture supernatants were collected and analyzed for CCL2 production with an ELISA kit (R\&D Systems), according to the manufacturer's instructions.

\section{EMSA}

RINm5F cells were pretreated with varying doses of celastrol for $1 \mathrm{~h}$, and then stimulated with cytokines $(5 \mathrm{ng} / \mathrm{ml} \mathrm{IL-1 \beta ,} 10$ $\mathrm{ng} / \mathrm{ml}$ TNF- $\alpha$, and $10 \mathrm{ng} / \mathrm{ml} \mathrm{IFN}-\gamma$ ) for $30 \mathrm{~min}$. Nuclear extracts were prepared, and the EMSA was performed as described previously (24). Nuclear extracts $(10 \mu \mathrm{g})$ were incubated with ${ }^{32} \mathrm{P}$-end labeled double-stranded NF-кB oligonucleotide (5'-AGT TGA GGG GAC TTT CCC AGG C-3'; Promega) in binding buffer (10 mM Tris-HCl, pH 8.0, $75 \mathrm{mM} \mathrm{KCl}, 2.5 \mathrm{mM}$ $\mathrm{MgCl} 2,0.1 \mathrm{mM}$ EDTA, $10 \%$ glycerol, $0.25 \mathrm{mM}$ DTT, and $1 \mu \mathrm{g}$ of poly $\mathrm{dl} / \mathrm{dC}$ ) for $30 \mathrm{~min}$. The DNA-protein complexes were analyzed by electrophoresis on a $6 \%$ native polyacrylamide gel in TBE buffer $(89 \mathrm{mM}$ Tris- $\mathrm{HCl}, 89 \mathrm{mM}$ boric acid, and 2 $\mathrm{mM}$ EDTA). Then, the gels were dried and examined by autoradiography.

\section{Statistical analysis}

Results are expressed as mean \pm standard deviation from at least three independent experiments. The values were evaluated by one-way analysis of variance, followed by Duncan's multiple range test using GraphPad Prism 4.0 software (GraphPad Software, Inc., San Diego, CA, USA). Null hypotheses of no difference were rejected if $P$ values were less than .05 .

\section{ACKNOWLEDGEMENTS}

This study was supported by the Priority Research Centers Program Grant (2009-0093812) and by a grant (2012R1A2A1A03006155) through the National Research Foundation of Korea funded by the Ministry of Education, Science, and Technology. This study was also supported by the Hallym University Specialization Fund (HRF-S-12).

\section{REFERENCES}

1. Eizirik DL, Colli ML and Ortis F (2009) The role of inflammation in insulitis and beta-cell loss in type 1 diabetes. Nat Rev Endocrinol 5, 219-226

2. Holohan C, Szegezdi E, Ritter T, O'Brien T and Samali A (2008) Cytokine-induced beta-cell apoptosis is NO-dependent, mitochondria-mediated and inhibited by BCL-XL. J Cell Mol Med 12, 591-606

3. Rabinovitch A and Suarez-Pinzon WL (1998) Cytokines and their roles in pancreatic islet beta-cell destruction and insulin-dependent diabetes mellitus. Biochem Pharmacol 55, 1139-1149

4. Southern C, Schulster D and Green IC (1990) Inhibition of insulin secretion by interleukin-1 beta and tumour necrosis factor-alpha via an L-arginine-dependent nitric oxide generating mechanism. FEBS Lett 276, 42-44

5. Chen MC, Proost P, Gysemans C, Mathieu C and Eizirik DL (2001) Monocyte chemoattractant protein-1 is expressed in pancreatic islets from prediabetic NOD mice and in interleukin-1 beta-exposed human and rat islet cells. Diabetologia 44, 325-332

6. Sarkar SA, Lee CE, Victorino F et al (2012) Expression and regulation of chemokines in murine and human type 1 diabetes. Diabetes 61, 436-446

7. Eizirik DL and Mandrup-Poulsen T (2001) A choice of death-- the signal-transduction of immune-mediated beta-cell apoptosis. Diabetologia 44, 2115-2133

8. Karin M and Delhase M (2000) The IкB kinase (IKK) and $\mathrm{NF}-\kappa \mathrm{B}$ : key elements of proinflammatory signaling. Semin Immunol 12, 85-98

9. Allison AC, Cacabelos R, Lombardi VR, Alvarez XA and Vigo C (2001) Celastrol, a potent antioxidant and anti-inflammatory drug, as a possible treatment for Alzheimer's 
disease. Prog Neuropsychopharmacol Biol Psychiatry 25, 1341-1357

10. Kannaiyan R, Shanmugam MK and Sethi G (2011) Molecular targets of celastrol derived from Thunder of God Vine: potential role in the treatment of inflammatory disorders and cancer. Cancer Lett 303, 9-20

11. Grant CW, Moran-Paul CM, Duclos SK, Guberski DL, Arreaza-Rubín G and Spain LM (2013) Testing Agents for Prevention or Reversal of Type 1 Diabetes in Rodents. PLoS One 8, e72989

12. Kim JE, Lee $\mathrm{MH}, \mathrm{Nam} \mathrm{DH}$ et al (2013) Celastrol, an $\mathrm{NF}-\kappa \mathrm{B}$ inhibitor, improves insulin resistance and attenuates renal injury in $\mathrm{db} / \mathrm{db}$ mice. PLoS One 8, e62068

13. Corbett JA and McDaniel ML (1992) Does nitric oxide mediate autoimmune destruction of beta-cells? Possible therapeutic interventions in IDDM. Diabetes 41, 897-903

14. Igoillo-Esteve M, Marselli L, Cunha DA et al (2010) Palmitate induces a pro-inflammatory response in human pancreatic islets that mimics CCL2 expression by beta cells in type 2 diabetes. Diabetologia 53, 1395-1405

15. Cardozo AK, Heimberg $H$, Heremans $Y$ et al (2001) A comprehensive analysis of cytokine-induced and nuclear factor-kappa B-dependent genes in primary rat pancreatic beta-cells. J Biol Chem 276, 48879-48886

16. Pirot $P$, Cardozo AK and Eizirik DL (2008) Mediators and mechanisms of pancreatic beta-cell death in type 1 diabetes. Arq Bras Endocrinol Metabol 52, 156-165

17. Cameron MJ, Arreaza GA, Grattan M et al (2000) Diffe- rential expression of CC chemokines and the CCR5 receptor in the pancreas is associated with progression to type I diabetes. J Immunol 165, 1102-1110

18. Zhao Y, Krishnamurthy B, Mollah ZU, Kay TW and Thomas HE (2011) NF-KB in type 1 diabetes. Inflamm Allergy Drug Targets 10, 208-217

19. Häcker $\mathrm{H}$ and Karin M (2006). Regulation and function of IKK and IKKrelated kinases. Sci STKE 2006, re13

20. Lee JH, Koo TH, Yoon H et al (2006) Inhibition of NF-kappa $\mathrm{B}$ activation through targeting I kappa $\mathrm{B}$ kinase by celastrol, a quinone methide triterpenoid. Biochem Pharmacol 72, 1311-1321

21. Kwon DJ, Bae YS, Ju SM, Youn GS, Choi SY and Park J (2014) Salicortin suppresses lipopolysaccharide-stimulated inflammatory responses via blockade of NF-KB and JNK activation in RAW 264.7 macrophages. BMB Rep 47, 318-323

22. Youn GS, Kwon DJ, Ju SM, Choi SY and Park J (2013) Curcumin ameliorates TNF- $\alpha$-induced ICAM- 1 expression and subsequent THP- 1 adhesiveness via the induction of heme oxygenase- 1 in the HaCaT cells. BMB Rep 46, 410415

23. Park MC, Kim D, Lee $Y$ and Kwon HJ (2013) CD83 expression induced by CpG-DNA stimulation in a macrophage cell line RAW 264.7. BMB Rep 46, 448-453

24. Shin SY, Kim CG and Lee YH (2013) Egr-1 regulates the transcription of the BRCA1 gene by etoposide. BMB Rep 46, 92-96 